\title{
Development of Smart Villages as a Factor for Rural Digital Transformation
}

\author{
Renāte Cāne \\ Faculty of Society and Science \\ Vidzeme University of Applied Sciences \\ Valmiera, Latvia \\ renate.cane@va.lv
}

\begin{abstract}
The concept of digital transformation, which refers to the use of strategically managed digital technologies to achieve various economic and social goals, is increasingly visible in various development programs of the European Union and Latvia. The aim of the digital transformation is to create a society, economy and public administration that purposefully uses the existing and creates new opportunities of digital technologies, improving the quality of life for every individual and society as well, raising the competitiveness of the country and economy.
\end{abstract}

The National Development Plan of Latvia for 2021-2027 also identifies the further development of digitalization as a pervasive element for all sectors, especially in such areas as innovation and science, education, health care, inclusive society and labor market, infrastructure, regional development, security, as well as also environment and energy. In order to do this, the "Digital Transformation Guidelines for 2021-2027" have been developed, which set out the goals, directions and tasks of the digital transformation policy.

One of the basic conditions for digital transformation is a digitally skilled society. To develop the rural environment, including through digital solutions, an initiative supported by the European Commission - 'Smart Villages', has been in place since 2016. It is a relatively new concept in EU policymaking and includes a vision for the future of rural areas. 'Smart', in the sense of this concept, means the development of new forms of cooperation - between farmers and other entrepreneurs in rural areas, between municipalities, the private and public sectors, and cooperation takes place from the bottom up and from the top down. Smart village strategies can ensure that the digital needs, priorities and capabilities of the rural population are addressed at local level and can help to link these core activities to national and regional digital strategies.

The aim of the research is to study the development opportunities of smart villages and their potential in the process of digital transformation of the rural environment. The study carried out an analysis of the rural and regional policies, as well as digital transformation strategic documents. The article also examines examples of the use of digital solutions in smart villages in European countries.

The study concludes that the introduction of the concept of smart villages is an effective tool for digital transformation in rural areas, both processes have a common goal and tasks, the most important of which is to take actions to prevent working-age persons from leaving local areas, moving to the capital city Riga or leaving Latvia.

Keywords - digitally skilled society, digital transformation, rural development, smart villages

\section{INTRODUCTION}

Looking at the development of the world economy and other social processes from a historical point of view, there is a clear significant trend - they are closely related to the development of various technologies and interact with each other. One classic example is the industrial revolution of the second half of the 19th century, in which manufacturers switched from manual to automated processes, resulting in increased revenue and production capacity. Today, we face a similar phenomenon, only in this case it occurs primarily in the digital environment, and it is a digital transformation [1].

The term 'digital transformation' has largely originated in the business environment and, in general, refers to the processes, cultures and customer experiences of using digital technologies to meet changing business and market requirements. Digital transformation has been defined differently in different sources, initially only emphasizing the need to integrate digital technologies into the company's business processes, until the current recognition that digital transformation requires not only technical solutions, but also review the company's strategy and culture, gradually including other aspects. Morakanyane, Grace \& O'Reilly (2017) defines digital transformation as "an evolutionary process in which a company integrates digital capabilities and technologies into its business 
models, processes, customer experience to create value" [2]. Rogers (2016) also acknowledges that "digital transformation is not based on technology, it is more related to the company's strategy and new ways of thinking, adapting to new market requirements and changing the company's strategy or even strategic direction accordingly” [3].

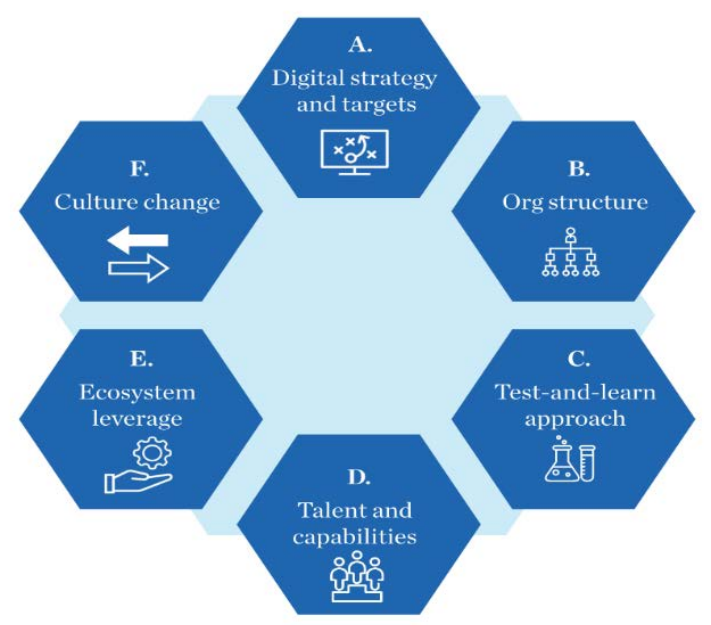

Fig. 1. McKinsey \& Company six key elements of digital transformation (source: McKinsey \& Company, 2018)

The main benefits of digital transformation are the opportunities to improve services, optimize processes and costs and increase efficiency, improve employee performance and promote internal cooperation, the creation of new business models, all of which increase the company's competitiveness.

In recent decades, business terminology has become increasingly used in the public and public sectors, and the notion of 'digital transformation', which refers to the use of strategically driven digital technologies to achieve a variety of economic and social goals, is no exception. Today, countries and public administrations around the world are changing their way of thinking, innovating and optimizing their IT infrastructure to respond more effectively to citizens' needs. One example is the UK Government, which has set up the Government Digital Service (GDS) to promote the digital transformation. The GDS service manages standards and best practices for other parts of the government as well as leading some successful digital transformation initiatives such as the development of Gov.uk, which hosts over half a million web pages whilst making the information accessible and consistent [4].

Latvia is also working towards digital transformation. The Ministry of Environmental Protection and Regional Development has prepared an important digital transformation strategy for Latvia - "Digital Transformation Guidelines 2021-2027.” which is currently in the public consultation before further adoption by the Cabinet of Ministers. The document defines the further development of digitalization in Latvia as a pervasive element of the whole sector, but especially touches on such areas as innovation and science, education, health care, inclusive society and labor market, infrastructure, regional development, environment and energy. The goal of digital transformation policy is to create a society, economy and public administration that purposefully uses the existing and creates new opportunities of digital technologies, improving the quality of life for every individual and society as a whole, raising the competitiveness of the state and economy [5]. It is planned to attract financing from the European Union Structural Funds, the state budget and other financial instruments for the implementation of the actions envisaged in the Guidelines.

The Organization for Economic Co-operation and Development's (OECD, 2018) report "Going Digital in the Multilateral World" sets out visions of how societal and economic development in different countries is expected in the context of such a global digital transformation and the main benefits. One of the directions evaluated is the nongovernmental (public) sector, in which the organized communities of the population are defined as a new central pillar that addresses national and local issues in a direct way, adapted to their needs. The report emphasizes the importance of identifying and developing the potential of digital infrastructure, as well as creating local and crossborder groups of like-minded people, addressing a range of issues relevant to these communities [6].

However, the positive outcome of this process may be hampered by a sharp digital divide between generations and rural-urban areas, and a polarization of society may develop, which may leave some communities at a lower level of development. Citizens living in less organized or active local or online communities are less able to defend their interests, lobby for state and municipal services, or promote economic activity in a territory or industry. The development, modernization and structural issues of digital technologies are a major challenge for rural communities across Europe, which are experiencing negative trends such as rural-urban migration and the aging of the local population. However, in order to provide the rural population with basic infrastructure and a comparable quality of life, not only modern technologies but also social innovations are needed. Smart villages, which are becoming an increasingly popular concept among EU Member States, are ready to resist these negative trends.

The aim of the research is to study the development opportunities of smart villages and their potential in the process of digital transformation of the rural environment. The main question of the research - how, using such a tool as smart villages, can the digital transformation of the rural environment in Latvia be promoted?

\section{METHODOLOGY OF THE RESEARCH}

This study is based on a descriptive and informative analysis of rural and regional policy as well as digital transformation strategic documents. The documents have been viewed at both the European Union and Latvian levels. In order to find out the migration tendencies of the Latvian rural population, a secondary analysis of statistical data was performed. 
The possibilities of digital transformation of the rural environment were studied using a case analysis approach. The paper presents examples of the use of digital solutions in smart villages in European countries. As the author of the study has been working for two years in the LEADER local action group "Sea Land” (Carnikava and Saulkrasti County Private and Public Partnership Association), she had the opportunity to study examples of smart village digital solutions in Scotland, as well as participate in exchange discussions with Finnish, Greek, Polish, Belgian, Welsh and Hungarian smart village practitioners. Based on this empirical experience and analysis, combined with document analysis and secondary data analysis, conclusions have been made and recommendations developed on how the development of smart villages in Latvia can contribute to the digital transformation process in rural areas.

\section{RESULTS AND DISCUSSION}

In many parts of the European Union, so-called rural areas are being adversely affected by a steady decline in population due to several mutually reinforcing reasons: insufficient labour supply, underdeveloped entrepreneurship, social and cultural opportunities, lack of everyday services and disorganized infrastructure. In Latvia, too, the population in rural and urban areas is changing every year, and in 2020, with a significant predominance, $80.24 \%$ of the population lived in cities and suburbs (densely populated areas), while in rural areas $-19.76 \%$ [7]. In addition, it must be emphasized that the population of rural areas is declining every year, and this is a stable trend.

TABLE 1 POPULATION OF RURAL AREAS (SPARSELY POPULATED) IN LATVIA (2016-2020)

\begin{tabular}{|l|l|}
\hline Year & Population of rural areas (sparsely populated) \\
\hline 2016 & 408560 \\
\hline 2017 & 403549 \\
\hline 2018 & 398138 \\
\hline 2019 & 382111 \\
\hline 2020 & 376459 \\
\hline
\end{tabular}

In order to halt the depopulation of rural areas and develop the rural environment, including through digital solutions, an initiative has been running since 2016, supported by the European Commission, based on the Smart Villages label.

In early September 2016, more than 340 rural stakeholders gathered in Cork, Ireland and developed a vision for the future of EU rural areas. Under the heading "A Better Life in Rural Areas", the Cork Declaration 2.0 sets out the expectations and aspirations of rural areas. Among the priorities to be addressed, it calls for policies to pay particular attention to overcoming the digital divide between rural and urban areas and to develop the potential offered by connectivity and digitisation of rural areas. Emphasis was given to the need for integrated approaches and the interaction between different policy fields in view of increasing complementarity and coherence [8].
Smart villages is a relatively new concept in EU policy-making and also includes a vision for the future of rural areas. 'Smart' in the sense of this concept means the development of new forms of cooperation - between farmers and other rural entrepreneurs, between municipalities, the private and public sectors, this bottomup and top-down cooperation, and includes the use of digital technologies when is practically applicable, but not because it is modern or contemporary. The challenge of digital technologies and innovation is to promote quality of life, a higher standard of living, public services for citizens, better use of resources, less impact on the environment and new opportunities for rural value chains in terms of products and improved processes.

It should be emphasized that smart villages are not based on technology, but on people - rural communities who take the initiative both in finding practical solutions and in tackling existing problems - the concept focuses on local people and their ability to use local resources and knowledge initiative.

Summarizing these guidelines, a definition of smart villages has been developed: "Smart villages are rural communities that can also include multiple localities, using their local strengths and values to develop new opportunities. It aims to create better public services, make more efficient use of local resources, promote lower environmental impact and innovate in order to improve the quality of life. There is no single solution for the implementation of a smart village, it is territorially sensitive and based on the wishes, needs and potential of the inhabitants of specific rural areas, and it is supported by new or existing territorial strategies” [8].

Placing the concept of smart villages in a broader context and comparing it with the main drivers of economic development in the 21st century (emergence of existing and new technologies, low carbon economy, circular economy, bio economy, new value and supply chains, new mobility models, closer rural-urban links) [9], it is possible to see a number of reasons for large-scale change that can give communities the necessary impetus for the digital transformation of the rural environment:

- Technological changes - for example, access to the Internet and new technologies can increase the use of precision agricultural machinery, which improves crop yields and the use of water and soil. Applied biotechnology promotes the production of new, more efficient crops, pest control and the restoration of ecosystems through bioremediation techniques;

- Demographic change - rising costs of living in big cities and new opportunities to work remotely, on the one hand, slow down rural depopulation and, on the other, encourage young people to return from cities to villages where they can work or set up businesses with a better quality of life;

- Economic change - for example, global consumer trends show a steady increase in organic farming and sustainable products, which are selling five times more 
than sustainable products. It provides greater added value for production in rural areas;

- Political change: the development of rural communities also depends on the initiative of local, national and supranational governments to provide infrastructure and support for start-ups through tax exemptions and funding. One example is the European Network for Rural Development's Smart Rural 21 program [10].

Smart village communities are based on the principle of participation in order to build their strategy for strengthening the economy, improving social and environmental conditions, with a special focus on digital solutions. As emphasized above, there is no one-size-fitsall solution to this goal, and each community can do so in a way that suits them and is resource-efficient. The following are a number of practical examples of how specific communities in Europe have implemented the smart village approach using today's digital opportunities.

Callander Hydro community. Callander is a small town (population 3 600) in the council area of Stirling, Scotland, situated on the River Teith. In 2012, LEADER supported a community group in Callander to drive their idea of building a mountain hydroelectric power station, converting rich mountain waters into green energy to generate income that could support other local community projects. The development and implementation of the project, which mostly involved the seniors of the town, took five years, its costs were about 2 million pounds, borrowing from two banks. Within six months, a hydroelectric power plant was built to produce electricity that is sold on the common electricity grid. The proceeds are used to repay the loan and raise around $£ 60,000$ a year to fund local activities and projects. Local volunteers are involved in the involvement and maintenance of the project. The loan will be repaid over a period of 10 years, after which all proceeds will be used for the community's own decisions. One of the future plans of the community is to create a fund in which to accumulate and increase money.

Aberfoyle Rural Business Center. Aberfoyle is a village in Loch Lomond and Trossachs National Park, Scotland, which has been a tourist favourite for over 100 years. However, over the last 20 years, the volume of tourism has been declining, and so has the demand for various local services and shops. In response, the community set up a Rural Entrepreneurship Center and received LEADER support for the recruitment of a staff member to coordinate economic recovery. These premises currently house the Aberfoyle Business Center, which offers shared and individual workplaces. It has helped to retain and attract the self-employed and other skilled professionals, especially those who need high-speed internet. Another example of local activity is a community service station. A private gas station in the village was forced to suspend its operations, but the local community bought the closed property to restore and continue its operation, thus retaining such an important service, as the nearest gas station is $15 \mathrm{~km}$ away.
Neighbouring local food project in the Stirling area. Neighbouring food is an online platform where buyers can order / buy specific local products, while sellers can choose the nearest market to meet their customers, as well as complete orders in a timely manner. Such online local food center models have already been set up in four communities in Scotland.

A similar solution for the agricultural sales network was developed in Germany, in the community of Bettzdorf/Siegen (Altenkirchen district) and in the community of Eisenberg and Gelheim (Donnersbergkreis). This project received a state grant of 180,000 euros and started in the research project Digital Villages. It examines how innovative digital technologies can help support and make life easier for people in rural areas. In both test regions, modular logistics systems were developed using digital technologies, based on a strong neighbourhood and ensuring a functioning delivery system at the local level [11].

There are many such examples in European countries and they have made a significant contribution to the digital transformation of rural areas. To support such initiatives, specific programs have been developed at EU level to provide communities with both knowledge and financial assistance. One of these programs is a project "Preparatory Action on Smart Rural Areas in the 21 st Century" (Smart Rural 21) - a two and a half-year project supported by the European Commission with the overall aim to promote and inspire villages to develop and implement smart village approaches and strategies across Europe, and to draw conclusions and support future policy interventions on smart villages. The project started in December 2019 and will conclude in June 2022 [12].

Within the framework of this project, Alsunga, which is one of the two villages in the second smallest municipality in Latvia with 1,390 inhabitants, became the first smart village in Latvia. In the fight for this status, 734 applications were submitted to Smart Rural 21, and 21 villages from different EU countries received support. Alsunga's society is mainly made up of people with a long cultural tradition, called suits. Alsunga is a good place to live, but ongoing depopulation is reducing available resources, thereby changing the living environment and the need for services. The main priorities are to develop sustainable local food and a craft market to increase marketing volumes for home-based producers. Another initiative is to develop the local school. Due to administrative reforms, the Alsunga municipality will be incorporated into a much larger municipality and will become an outskirts parish. This will require the development of a strong village strategy and team to keep the development of Alsunga.

The development of Alsunga as a smart village was formed step by step. By bringing together people from different population groups with different views, the strengths and values of the local area were assessed, and practical solutions to the challenges facing the local area and its inhabitants were sought. In the first years, local activists learned to talk to each other, learned to work 
together. Regular meetings of local community activists set goals for which those responsible and their assistants were appointed. All together make sure that the goal is achieved step by step. The smart village movement in Alsunga began with the joint organization of clean-ups and the clean-up of the local area. The smart village initiative has been able to unite different generations. Children and young people are also involved with interest, territories are being improved, playgrounds and recreation places for young people are being created, larger and smaller events are being organized. The co-creation space has also been created, and the environment of Alsunga Secondary School has become more interesting and cognitive for young people. By implementing new forms of cooperation and evaluating the opportunities provided by digital technologies, the residents of Alsunga are currently working on a mobile phone application to promote cooperation between tourism entrepreneurs [13].

Today, the smart village of Alsunga boasts a strong and creative team of more than 40 active locals. However, one of the most significant benefits is that several families with children have returned to life in Alsunga in recent years. This shows that the smart village strategy has had the effect of stopping the external migration of the population.

As already mentioned, Alsunga was the first successful smart village project in Latvia with followers. This approach was also used in Skujene, Amata region, combining existing values with digital communication technologies. In the pilot project on smart villages in coastal areas, one of the participants is the village of Pape in Rucava region.

In February 2021, an international co-operation project "On the way to smart landfall” was launched in Latvia, the aim of which is to acquaint coastal residents with the concept of smart village development and start its gradual pilot implementation in each of the six coastal areas selected by co-operation partners. The project will mobilize local coastal communities by educating their leaders, strengthening the identity of villages and neighbourhoods, and promoting sustainable development based on modern knowledge and innovation and the emergence of new social and economic cooperation. The six pilot sites of this project are both villages (e.g. Kaltene, Bernati, Ainazi), neighbourhoods (e.g. Libiesu krasts and Lapmezciems neighborhood), as well as rural town Carnikava [14].

Another new initiative has also been launched in March 2021 - the Latvian communities will have the opportunity to receive the "Smart Village" label. The competition has received an unexpected response: 38 applications have been submitted to the evaluation and the large number of applications points to the civic maturity of the community and its members. The results will be announced during the fifth Latvian Parliament of Rural Communities [15].

The criteria to be met in order to be able to give the "Smart Town" awareness mark clearly show the factors needed to allow the village or neighbourhood to start on the path towards the status of a smart village: 1 ) there must be an open and co-operative population that is actively involved in improving the quality of life of their community, is aware of the community's identity, common values and motivation, and sees a goal and vision for achieving it; 2) the village must be open to the implementation of innovative solutions in one of the three areas: business, social or technological environment; 3) the community must be aware of the technical, territorial, financial and human resources available to the village, as well as develop the knowledge and competencies of the population; 4) population management must be integrated and open, with a clear governance structure, and the decision-making process must be bottom-up [16].

There is no standardized approach to the implementation and digitization of smart villages, they determine the specifics of each specific rural area, and therefore each community must define its own goals, identify its own resources, and develop its own plan for its implementation. The directions in which solutions can be sought for the digital transformation of the rural environment are very diverse:

- E-government and community participation in social platforms;

- E-commerce, new digital markets and / or new niche products;

- 'Smart' agriculture;

- Smart tourism solutions;

- Energy saving solutions, renewable energy;

- Food supply systems;

- Logistics, e-mobility, car sharing;

- Co-working, also in e-environment;

- Distance learning;

- E-medicine, telemedicine;

- New digital environment approaches to housing and construction [17].

Equally diverse are innovations and new digital technologies that can contribute to the development of rural communities today:

- IoT: the Internet of Things is linked to the concept of smart cities, but is also applicable in rural areas. For example, using sensors that allow crops to be more competitive or applied to education and health in isolated areas;

- Artificial intelligence: the adoption of artificial intelligence systems is directly applicable to improving crops and environmental management, as well as in optimising health services and infrastructure use;

- Big Data: the huge amount of data generated today (Big Data), allows changes in climate to be analysed accurately along with water consumption, livestock movements, the growth of pastures and forests, and other essential information;

- Drones: thanks to the use of drones, hectares of land can be monitored automatically thereby collecting 
data on temperature, crop status, animal movements or controlling the spread of pests, thus improving the use of pesticides;

- Blockchain: according to the United Nations Food and Agriculture Organization (FAO), blockchain technology can be used to increase efficiency, transparency and traceability in agricultural supply chains and make them more productive and sustainable;

- Nanomaterials: the use of smart materials has the potential to enhance sensors, apply fertilisers, pesticides and protective layers that improve food safety, eliminate waste and even mitigate the effects of climate change on plants;

- Robots: from autonomous tractors that do not need a driver to robots capable of picking delicate fruits one by one without damaging them, the introduction of robots in rural areas is driving a revolution in efficiency and sustainability [18].

One of the basic conditions for digital transformation is a digitally skilled society. Although the opportunities provided by the digital environment in rural development are wide, the question remains: are the people of Latvia ready for a rapid transition to digital transformation, which includes the acquisition of fundamentally new knowledge and skills for almost every profession. A research conducted by Norstat in December 2020 found that only $31 \%$ of Latvians surveyed said that their skills and knowledge were sufficient to work with new digital tools and compete in the digital transformation era. There are also differences between age groups: while $53 \%$ of 20-29 year olds recognized their skills as meeting the requirements of the digital transformation age, $22 \%$ of 40 59 year olds and 60-74 year olds for seniors - only $13 \%$. Only $12 \%$ of seniors aged $60-74$ have attended professional development courses in the last six months. Among those in their thirties, this proportion was 27\%. The research also highlighted the gap between Riga, Pieriga and the regions. If in the last six months (during Covid-19) 38\% of the respondents had acquired new digital skills in Pieriga, then in Kurzeme and Vidzeme only $28 \%$. If in this period $27 \%$ of digital skills learners in Latgale had attended appropriate professional development courses, then in Vidzeme - only 8\%. In the last six months, $48 \%$ of respondents had worked remotely in Pieriga and $46 \%$ in Riga, but in Kurzeme and Vidzeme they were only $26 \%$ and $29 \%$, respectively [19]. This is very unpleasant data, which unfortunately does not bode well for the public's readiness to take advantage of the great potential of digitization.

Therefore, as an important step in the Digital Transformation Guidelines 2021-2027: “To ensure that every citizen in need, regardless of age, social status and level of security, including children, young people, SMEs, needs, seniors, digital agents, etc. groups, coordinated cooperation between different institutions, NGOs and the social partners is needed [17]." There is also a clear need for a well-targeted, sustained and consistent contribution from EU funds and public budgets to break the vicious circle, which is also acknowledged in the document's recognition that none of the public authorities, municipalities or organizations [20]. Therefore, it is important to concentrate the efforts of the whole society to solve this problem, which hinders digital transformation not only in rural areas, but throughout Latvia.

\section{CONCLUSIONS}

One of the basic conditions for digital transformation is a digitally skilled society. Smart village strategies can ensure that the digital needs, priorities and capabilities of the rural population are addressed at local level and can help to link these key actions to wider national and regional digitization strategies. Smart villages strategies can also help bridge the digital divide between areas with different levels of digital development by identifying the different levels of digital maturity in rural areas and villages and jointly developing solutions for digital skills.

A smart village is one that responds not only to challenges but also to new technological opportunities. However, Alsunga's and other smart villages in Latvia experience shows that without strong support, the "lifting" of smart villages is not possible, as well as the support of the municipality. It is therefore important to identify and implement the factors and conditions needed to ensure that smart villages support systems help rural communities to engage in the digital transformation process, regardless of their starting point, and to become digital innovators and creators of economic, social and environmental value.

The study concludes that the introduction of the concept of smart villages is an effective tool in the digital transformation of rural areas, both processes have a common goal and tasks, the most important of which is to prevent people of working age from leaving local areas when moving to the capital or leaving Latvia.

\section{REFERENCES}

[1] T. Saldanha, Why Digital Transformations Fails: The Surprising Disciplines of How to Take Off and Stay Ahead. Berrett-Koehler Publishers, 2019.

[2] R. Morakanyane, A. Grace, P. O’Reilly, Conceptualizing Digital Transformation in Business Organizations: A Systematic Review of Literature. University of Maribor Press, 2017.

[3] D. Rogers, The Design Thinking Playbook. ASV: Springer (2016).

[4] About the Government Digital Service, 2021. [Online]. Available: https://gds.blog.gov.uk/about/ [Accessed: March 21, 2021.]

[5] Digitālās transformācijas pamatnostādnes 2021.-2027.gadam, Projekts, 2021. [Online]. Available: https://www.varam.gov.lv/sites/varam/files/content/files/digitalastransformacijas-pamatnostadnes-_2021-27.pdf [Accessed: March $12,2021]$

[6] OECD, Going Digital in a Multilateral World, 2018. [Online]. Available: https://www.oecd.org/going-digital/C-MIN-2018-6EN.pdf [Accessed: March 20, 2021]

[7] Centrālās Statistikas pārvaldes datubāzes, Iedzīvotāji, Teritoriālā statistika, RIG060 Pilsētu un lauku iedzīvotaju skaits regionos, pilsētās, novados un pagastos (eksperimentālā statistika). [Online]. Available:

https://data.csb.gov.lv/pxweb/lv/iedz/iedz riga/RIG060.px [Accessed: March 3, 2021]

[8] European Commission, EU Action for Smart Villages. [Online]. Available: https://ec.europa.eu/info/sites/info/files/food-farmingfisheries/key_policies/documents/rur-dev-small-villages_en.pdf [Accessed: March 6, 2021] 
Environment. Technology. Resources. Rezekne, Latvia Proceedings of the $13^{\text {th }}$ International Scientific and Practical Conference. Volume 1, 43-49

[9] European Network of Rural Development, How to support Smart Villages strategies which effectively empower rural communities? Orientations for policy-makers and implementers. [Online]. Available:

https://enrd.ec.europa.eu/sites/enrd/files/enrd_publications/smartvillages orientations_sv-strategies.pdf [Accessed: March 6, 2021]

[10] Smart Villages, when technology arrives at a village to stay. [Online]. Available: https://www.iberdrola.com/innovation/smartvillage-smart-towns [Accessed: March 15, 2021]

[11] Projekt „Digitale Dörfer“ - Land fördert Testregionen Betzdorf und Eisenberg/Göllheim. [Online]. Available: https://www.digitale-doerfer.de/projekt-digitale-doerfer-landfoerdert-testregionen-betzdorf-und-eisenberggoellheim/ [Accessed: March 6, 2021]

[12] The 'Preparatory Action on Smart Rural Areas in the 21st Century', The Smart Rural 21 Project. [Online]. Available: https://www.smartrural21.eu/smart-rural-21-project/about/ [Accessed: March 16, 2021]

[13] Lauku tīkls, Kāds ir īstens viedais ciems. [Online]. Available: http://www.laukutikls.lv/nozares/lauku-telpa/raksti/kads-ir-istensviedais-ciems [Accessed: March 2, 2021]

[14] Projekts "Ceḷā uz viedumu piekrastēs". [Online]. Available: https://juraszeme.lv/sadarbibas-projekti/projekts-cela-uzviedumu-piekrastes/ [Accessed: May 8, 2021]
[15] Sākusies pieteikumu vērtēšana atpazīstamības zīmes "Viedais Ciems" pieškiršanai. [Online]. Available: https://laukuforums.lv/lv/archives/12220 [Accessed: May 8, 2021]

[16] Atpazīstamības zīmes „Viedais Ciems” piešķiršanas kritēriji. [Online]. Available: https://laukuforums.lv/wpcontent/uploads/2021/02/11012021_Kriteriji_ViedsCiems.pdf [Accessed: May 8, 2021]

[17] Ā. Ādlers, Kas ir viedais ciems. Projekts "Viedo Ciemu attīstības piekrastes teritorijā”, 2019. [Online]. Available: https://lrpartneriba.lv/wp-content/uploads/Viedie_Ciemi.pptx.pdf [Accessed: March 8, 2021]

[18] Smart Villages, when technology arrives at a village to stay. [Online]. Available: https://www.iberdrola.com/innovation/smartvillage-smart-towns [Accessed: March 20, 2021]

[19] R. Strazdiṇa, Digitālās transformācijas stratēǵijas īstenošana nav atliekama, portāls Ir.lv, 9.02.2021. [Online]. Availaible: https://ir.lv/2021/02/09/digitalas-transformacijas-strategijasistenosana-nav-atliekama/ [Accessed: March 20, 2021]

[20] Digitālās transformācijas pamatnostādnes 2021.-2027.gadam, Projekts, 2021. [Online]. Available: https://www.varam.gov.lv/sites/varam/files/content/files/digitalastransformacijas-pamatnostadnes-_2021-27.pdf [Accessed: March 20, 2021] 